\title{
Article \\ Oenothein B in Eucalyptus Leaf Extract Suppresses Fructose Absorption in Caco-2 Cells
}

\author{
Keiichiro Sugimoto ${ }^{1,2, *} \mathbb{D}$, Midori Amako ${ }^{2}$, Hiroaki Takeuchi ${ }^{1}$, Kazuya Nakagawa ${ }^{1}$, Morio Yoshimura ${ }^{3}$, \\ Yoshiaki Amakura ${ }^{3}$, Tomoyuki Fujita ${ }^{4}$, Shigeo Takenaka ${ }^{5}$ and Hiroshi Inui ${ }^{5,6}$ \\ 1 Research and Development Center, Nagaoka Co., Ltd., Ibaraki, Osaka 567-0005, Japan; \\ htakeuchi@npc-nagaoka.co.jp (H.T.); knakagawa@npc-nagaoka.co.jp (K.N.) \\ 2 Center for Research and Development of Bioresources, Osaka Prefecture University, Sakai, \\ Osaka 599-8570, Japan; amakom@bioinfo.osakafu-u.ac.jp \\ 3 Department of Pharmacognosy, College of Pharmaceutical Sciences, Matsuyama University, Ehime, \\ Matsuyama 790-8578, Japan; myoshimu@g.matsuyama-u.ac.jp (M.Y.); amakura@g.matsuyama-u.ac.jp (Y.A.) \\ 4 Department of Agriculture, Graduate School of Science and Technology, Shinshu University, \\ Nagano 399-4598, Japan; tfujita@shinshu-u.ac.jp \\ 5 Department of Nutrition, College of Health and Human Sciences, Osaka Prefecture University, Habikino, \\ Osaka 583-8555, Japan; takenaka@rehab.osakafu-u.ac.jp (S.T.); inui@biochem.osakafu-u.ac.jp (H.I.) \\ 6 Department of Health and Nutrition, Otemae University, Osaka 540-0008, Japan \\ * Correspondence: ksugimoto@npc-nagaoka.co.jp; Tel.: +81-72-623-5252
}

check for updates

Citation: Sugimoto, K.; Amako, M.; Takeuchi, H.; Nakagawa, K.; Yoshimura, M.; Amakura, Y.; Fujita, T.; Takenaka, S.; Inui, H. Oenothein B in Eucalyptus Leaf Extract Suppresses Fructose Absorption in Caco-2 Cells. Molecules 2022, 27, 122. https://doi.org/10.3390/ molecules27010122

Academic Editor: George Grant

Received: 16 November 2021

Accepted: 22 December 2021

Published: 26 December 2021

Publisher's Note: MDPI stays neutral with regard to jurisdictional claims in published maps and institutional affiliations.

Copyright: (c) 2021 by the authors Licensee MDPI, Basel, Switzerland. This article is an open access article distributed under the terms and conditions of the Creative Commons Attribution (CC BY) license (https:// creativecommons.org/licenses/by/ $4.0 /)$.

\begin{abstract}
Inhibition of fructose absorption may suppress adiposity and adiposity-related diseases caused by fructose ingestion. Eucalyptus leaf extract (ELE) inhibits intestinal fructose absorption (but not glucose absorption); however, its active compound has not yet been identified. Therefore, we evaluated the inhibitory activity of ELE obtained from Eucalyptus globulus using an intestinal fructose permeation assay with the human intestinal epithelial cell line Caco-2. The luminal sides of a cell monolayer model cultured on membrane filters were exposed to fructose with or without the ELE. Cellular fructose permeation was evaluated by measuring the fructose concentration in the medium on the basolateral side. ELE inhibited $65 \%$ of fructose absorption at a final concentration of $1 \mathrm{mg} / \mathrm{mL}$. Oenothein B isolated from the ELE strongly inhibited fructose absorption; the inhibition rate was 63\% at a final concentration of $5 \mu \mathrm{g} / \mathrm{mL}$. Oenothein B did not affect glucose absorption. In contrast, the other major constituents (i.e., gallic acid and ellagic acid) showed little fructose-inhibitory activity. To our knowledge, this is the first report that oenothein B in ELE strongly inhibits fructose absorption in vitro. ELE containing oenothein B can prevent and ameliorate obesity and other diseases caused by dietary fructose consumption.
\end{abstract}

Keywords: eucalyptus leaf extract; fructose absorption; oenothein B; polyphenol; hydrolyzable tannins; ellagitannin; glucose transporter 5; Caco-2 cell; polyvinylpolypyrrolidone

\section{Introduction}

Fructose consumption has increased in the past five decades because of the use of high-fructose corn syrups as sweeteners in beverages and processed foods [1,2]. Sucrose is also ingested in large amounts, as it is traditionally used in many foods and beverages [3]. Excess fructose intake induces adiposity [1,2,4,5], fructation (a kind of glycation caused by amino-carbonyl reactions with fructose) [5,6], and insulin resistance [2,5,7,8], which can lead to the development of nonalcoholic fatty liver disease (NAFLD) $[9,10]$, diabetes mellitus [1,7], and hypertension [1,11]. Malik et al. have reported that consumption of beverages sweetened with sugar and/or artificial sweeteners is positively related to mortality [12]. The World Health Organization has suggested that the consumption of such sugars should be reduced to less than $10 \%$ of the total energy intake but insists that it is desirable to reduce it to within 5\% (roughly $25 \mathrm{~g}$ (six teaspoons) per day) in a published guideline for sugar intake [13]. 
Fructose is more lipogenic than glucose in the liver because its metabolic pathway does not include the step catalyzed by 6-phosphofructokinase, the main rate-controlling enzyme in glycolysis; therefore, large amounts of ingested fructose can be rapidly metabolized without metabolic regulation [14]. Fructose serves as the carbon source for both the glycerol and acyl portions of triacylglycerol molecules, leading to de novo lipogenesis $[2,5]$.

Fructose is passively incorporated from the luminal side of the intestine across membranes by glucose transporter 5 (GLUT5), one of the facilitative GLUT family members [15]. GLUT5 is the sole fructose-specific transporter and does not transport glucose or galactose; transapical transport of fructose in the intestine is mediated primarily via GLUT5 [11,15]. Furthermore, GLUT5 plays an initial role in the development of hypertension induced by fructose consumption [11]. A clinical trial on isocaloric fructose restriction in diets demonstrated that children with obesity showed a consistent decrease in de novo lipogenesis in the liver within a short period. Subsequently, their hepatic and visceral fat levels were improved [16]. In a similar study in obese children, glucose and lipid metabolism were improved [17]. In a trial, diets of overweight adults with fatty liver were supplemented with glucose or fructose daily. After 6 weeks, a significant decrease in the intrahepatic lipid content was observed in the glucose group compared to the fructose group [18]. A restriction of fructose intake in the diet for 24 weeks reduced waist circumference and fasting blood glucose concentration in overweight and obese adults [19]. Therefore, inhibiting GLUT5 could be an important strategy for preventive medicine or for therapeutic intervention for the foregoing diseases caused by excessive fructose ingestion.

The evergreen tree Eucalyptus globulus Labill (Myrtaceae), native to Tasmania, Australia, is globally distributed. Eucalyptus leaves are used to prepare herbal tea in Europe [20] and are traditionally used as a natural remedy for diabetes mellitus in South America and Africa [21]. The extract of the leaves (eucalyptus leaf extract; ELE) has recently been used as a functional food or in cosmetics because of its beneficial effects, such as antioxidative [22,23], anticaries [24], and anti-skin-aging properties [25]. The safety of ELE was reported by the Japanese Ministry of Health, Labor and Welfare based on the results of several mutagenesis assays, mouse bone marrow micronucleus assays, and a 90-day repeated dose toxicity study [26]. We previously reported the safety assessment of oral ELE administration for 4 weeks in adult men [27]. Furthermore, we reported that ELE inhibits fructose absorption in the intestine and suppresses the accretions of visceral fat and hepatic triacylglycerols induced by excessive fructose ingestion in rats [28]. This inhibitory effect on intestinal fructose absorption has also been observed in human subjects [29]. However, the inhibitory constituent of fructose absorption in ELE has not yet been identified. Therefore, we aimed to identify the active constituents of ELE by performing an in vitro intestinal fructose absorption assay using the human intestinal epithelial cell line Caco-2.

\section{Results and Discussion}

\subsection{Inhibitory Activities of ELE on Fructose Absorption}

Dietary fructose is incorporated into the intestinal tract through GLUT5 at the apical side of the cells and transported to the portal vein via GLUT2 at the basolateral side [15,30]. Caco-2 cell line spontaneously differentiates into enterocytes, which possess various characteristics of the small intestine, such as brush border membrane enzymes and nutrient transporters, including GLUT5 [31]. The cell line has been used in various fructose transport studies [32]. We examined the effects of ELE and its constituents on fructose permeation across an intestinal epithelial cell monolayer model from the luminal side to the basolateral side using Caco-2 cells to identify the active constituent of the extract. Before evaluating the inhibitory effect of ELE on fructose absorption using Caco-2 cells, we confirmed that GLUT5 regulates fructose absorption in this model; we verified that cytochalasin B [33], a GLUT2 inhibitor, does not affect fructose absorption at a final concentration of $100 \mu \mathrm{mol} / \mathrm{L}$ (the inhibitory rate on glucose absorption was 31\%). 
ELE strongly inhibited fructose absorption at a final concentration of $1 \mathrm{mg} / \mathrm{mL}$ in Caco-2 cells (Table 1). At this dose, ELE-treated cells did not show different morphological features, as confirmed by transepithelial/endothelial electrical resistance (TEER) and microscopic analyses; before and after fructose permeation, the TEER values of the blank and ELE (1 mg/mL) were retained by $91 \%$ and $81 \%$, respectively. Many studies have reported various polyphenols derived from edible plants with inhibitory activity against fructose absorption [32,34-43]. We examined the effects of the ELE with reduced polyphenolic substances. Polyvinylpolypyrrolidone (PVPP) has high affinity for polyphenols, and, therefore, the removal of PVPP using centrifugation, following the treatment, removes polyphenols from the extract [44]. PVPP treatment considerably reduced the total polyphenol content and PVPP-treated ELE (yield, 26\%) showed weak inhibition on intestinal fructose absorption (Table 1), suggesting that polyphenols were the main active constituents of the ELE.

Table 1. Total polyphenol content and inhibitory effects of ELE on fructose absorption.

\begin{tabular}{cccc}
\hline Sample & Total Polyphenols (\%) & Dose $(\mathbf{m g} / \mathbf{m L})$ & Inhibition ${ }^{\mathbf{1}} \mathbf{( \% )}$ \\
\hline ELE & 30 & 1 & 65 \\
PVPP-treated ELE & 5 & 0.26 & $<20$ \\
\hline
\end{tabular}

${ }^{1}$ Each value represents the mean of two experiments.

\subsection{Identification of the Fructose Absorption Inhibitor in ELE}

The profiles of the ELE constituents were analyzed using HPLC with a diode-array detector (DAD). Figure 1a shows the three-dimensional chromatogram between 220 and $400 \mathrm{~nm}$. Among the detected compounds, oenothein B (1), gallic acid (2), ellagic acid (3), quercetin 3-O- $\beta$-D-glucuronide (4), and kaempferol 3-O- $\beta$-D-glucuronide (5) were identified as the major constituents of ELE with a similar profile as that presented in a previous report [23]. Figure 2 shows the chemical structures of the compounds 1-5. We evaluated the inhibitory activity of these constituents on fructose absorption (Table 2). Among them, compound 1 strongly inhibited fructose absorption. We also evaluated the effect of $\mathbf{1}$ on glucose absorption, because ELE administration barely affected the postprandial increase in blood glucose levels in vivo [28,29]. This constituent did not affect glucose absorption (data not shown).

Compound $\mathbf{1}$ is a hydrolyzable tannin characterized by the presence of a glucopyranose core that is esterified by polyphenolic acids, such as a hexahydroxydiphenoyl (HHDP) unit and compound 2. Tannins, including compound 1, have diverse biological effects, such as antioxidant, anti-inflammatory, antitumor, enzyme inhibitory, and antimicrobial effects [45]. To our knowledge, compound 1 is the first to be identified as an inhibitor of fructose absorption from hydrolyzable tannins.

Compounds 2 and 3, which are hydrolysates of hydrolyzable tannins, barely inhibited fructose absorption. Compounds 4 and 5 also showed a similar trend. Satsu et al. have reported that compound 2 and quercetin (aglycon of compound 4) did not inhibit fructose incorporation into Caco-2 cells, whereas kaempferol (aglycon of compound 5) showed a weak inhibition [41]. We also examined the inhibitory effect of quercetin on fructose permeation and found little inhibition (less than $30 \%$ ) at a dose of $50 \mu \mathrm{g} / \mathrm{mL}$.

Gonçalves et al. stated that modulating intestinal fructose absorption via GLUT5 and/or GLUT2 might provide a novel pharmacologic strategy for diseases caused by excessive fructose consumption [30]. Recent studies have shown that ingestion of fructose beyond the fructose clearance capacity of the intestine leads to leakage of incorporated fructose into the portal vein, thus forcing the liver to metabolize the excess fructose to produce fat. When an appropriate amount of fructose is taken up by individuals, it is converted to other substances by metabolic enzymes, such as ketohexokinase, in the intestinal tract, and de novo lipogenesis in the liver is mitigated [46]. Restriction of fructose intake improved lipid metabolism and obesity in certain dietary intervention trials [16-19]. Therefore, limiting fructose intake even slightly might be beneficial for people who consume 
excessive amounts of fructose. Many studies have reported that polyphenol intake reduces the risk of diseases, such as obesity and type 2 diabetes mellitus. Loureiro et al. suggest that inhibition of intestinal absorption of glucose and fructose is a potent mechanism that could help manage these diseases [40]. Although the inhibitory effects of compound 1 on intestinal fructose absorption need to be confirmed in in vivo experiments, ELE containing $\mathbf{1}$ is expected to have preventive and inhibitory effects on fructose-derived obesity and related diseases.

\section{(a)}
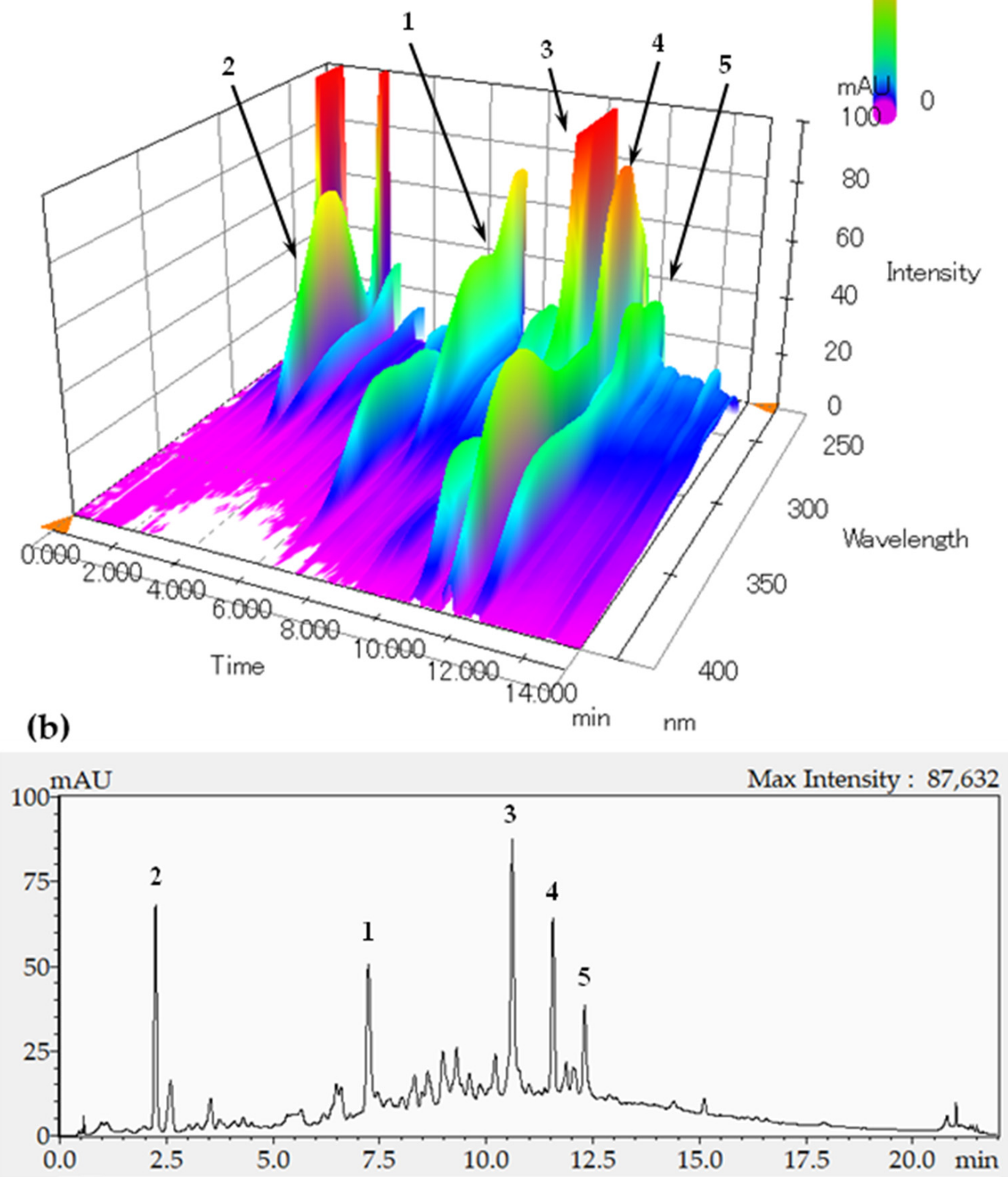

Figure 1. HPLC profiles of ELE recorded for UV absorption from 220 to $400 \mathrm{~nm}$ (a) and at $270 \mathrm{~nm}$ (b). The retention times of compounds $\mathbf{1}-\mathbf{5}$ were $7.24,2.25,10.52,11.56$, and $12.31 \mathrm{~min}$, respectively. 


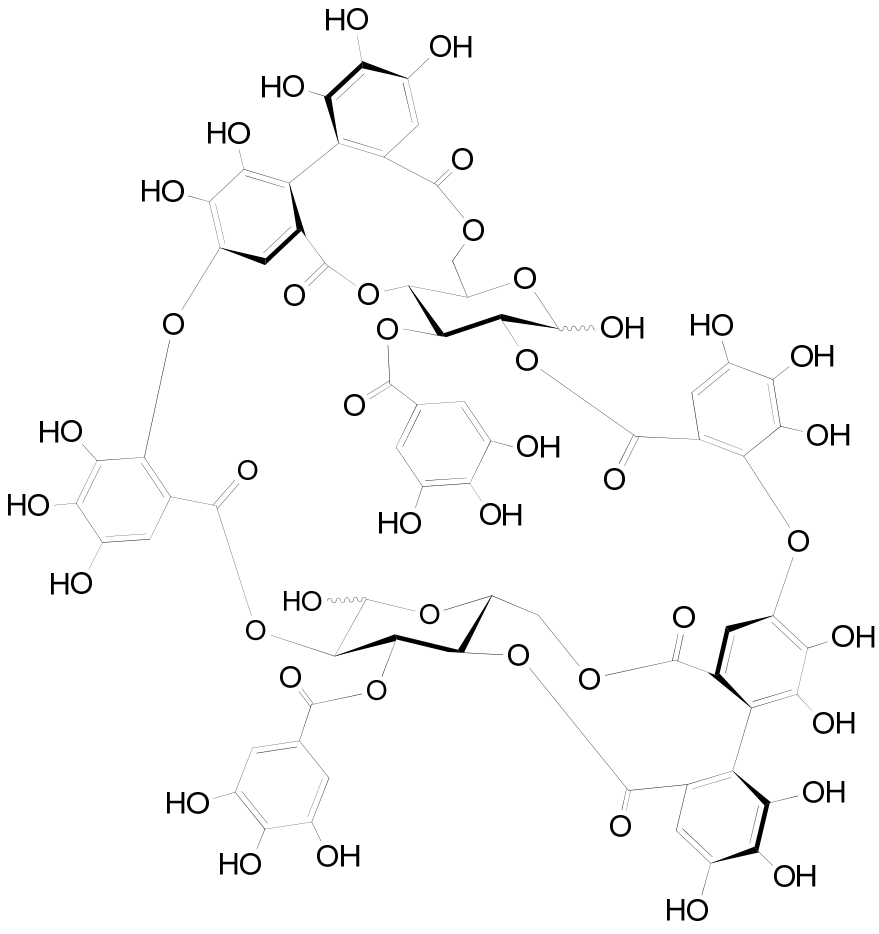

Oenothein B (1)<smiles>O=C(O)c1cc(O)c(O)c(O)c1</smiles>

Gallic acid (2)<smiles>O=C1c2cc(O)c(O)c3oc(=O)c4oc(=O)c5cc(O)c(O)c1c5c4c23</smiles>

Ellagic acid (3)<smiles>O=C(O)C(O)CC(O)CC(O)Oc1c(-c2ccc(O)c(O)c2)oc2cc(O)cc(O)c2c1=O</smiles>

Quercetin 3-O- $\beta$-D-glucuronide (4)

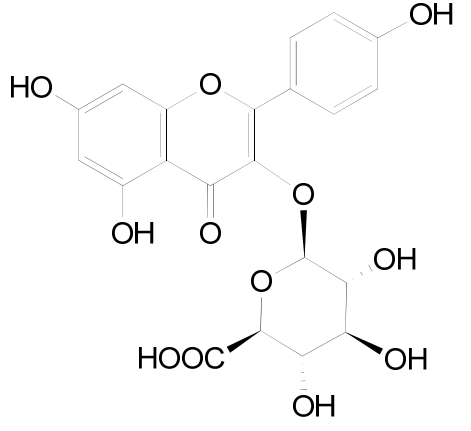

Kaempferol 3-O- $\beta$-D-glucuronide (5)

Figure 2. Chemical structures of the major constituents of the ELE.

Table 2. Inhibitory effect of constituents of eucalyptus leaf extract on fructose absorption.

\begin{tabular}{ccc}
\hline Sample & Dose $(\boldsymbol{\mu g} / \mathbf{m L})$ & Inhibition ${ }^{\mathbf{1}} \mathbf{( \% )}$ \\
\hline Oenothein B (1) & 5 & 63 \\
Gallic acid (2) & 50 & $<20$ \\
Ellagic acid (3) & 50 & $<30$ \\
Quercetin 3-O- $\beta$-D-glucuronide (4) & 50 & $<30$ \\
Kaempferol 3-O- $\beta$-D-glucuronide (5) & 50 & $<30$ \\
\hline
\end{tabular}

${ }^{1}$ Each value represents the mean of two experiments.

We previously reported that compound $\mathbf{1}$ is a major constituent and a significant chemical marker of the E. globulus leaf; it is a rare natural product and can be detected easily without interference from other peaks on the ELE chromatogram [23]. We considered 
that compound $\mathbf{1}$ may be the main constituent of the ELE possessing inhibitory activity for fructose absorption.

Next, we attempted to develop a quantitative analysis method for compound $\mathbf{1}$. The peak for compound $\mathbf{1}$ appeared almost independently in the chromatogram of the ELE recorded at $270 \mathrm{~nm}$ (Figure $1 \mathrm{~b}$ ), although a small contamination peak was observed around the retention time of $7.5 \mathrm{~min}$. We isolated compound $\mathbf{1}$ as an analytical standard from ELE using preparative methods described previously [23]. The peak for compound 1 was identified using HPLC coupled to electrospray ionization mass spectrometry (ESI-MS). The peak for compound $\mathbf{1}$ appeared around $7.24 \mathrm{~min}$ in the chromatograms of the ELE (Figure 3a) and the isolated compound 1 (Figure 3b). The MS/MS fragmentations of the peaks that appeared around $7.24 \mathrm{~min}$ also showed almost the same patterns upon the comparison of the following ions: $[\mathrm{M}-2 \mathrm{H}]^{2-}$ at $m / z 783.00$ as a precursor ion and product ions at $m / z$ 765.00, 300.85, and $275.00[47,48]$ between the ELE (Figure 3c) and isolated compound 1 (Figure 3d).
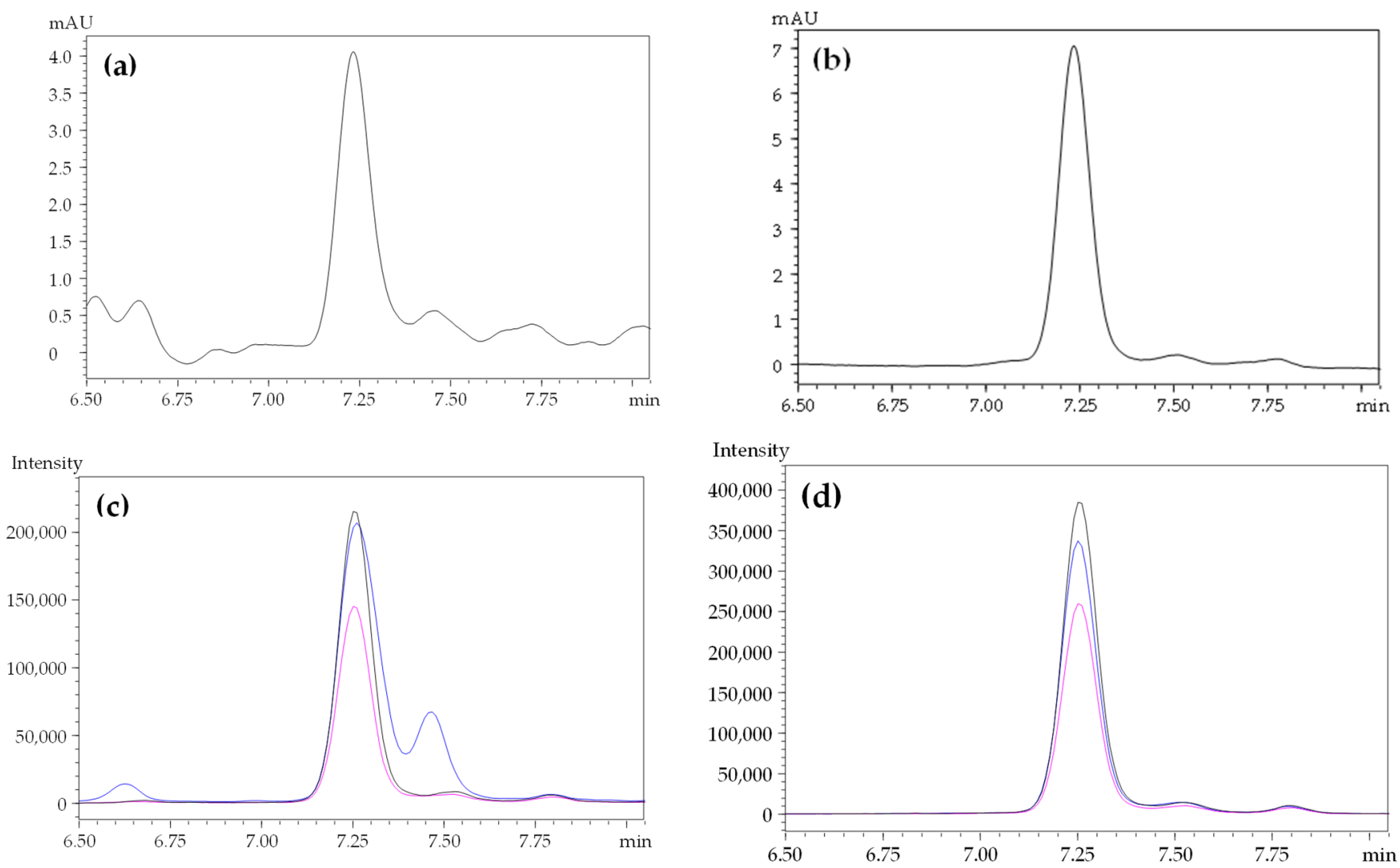

Figure 3. Comparisons of the UV chromatograms and MS/MS profiles of ELE and the purified oenothein B (1). (a,c), ELE; (b,d), purified compound 1. (a,b) show HPLC chromatograms recorded at $270 \mathrm{~nm}$. (c,d) show MS/MS profiles in the negative ion mode at $m / z 765.00$ (black), 300.85 (blue), and 275.00 (pink).

Baert et al. [47] reported the UV calibration curve of 1 with linearity for concentrations ranging from 0.3 to $150 \mu \mathrm{g} / \mathrm{mL}\left(\mathrm{R}^{2}=0.9984\right)$ and a limit of quantitation (LOQ) of $0.88 \mu \mathrm{g} / \mathrm{mL}$. However, solutions of the isolated substance showed large variabilities in the low-concentration group $(<10 \mu \mathrm{g} / \mathrm{mL})$. Although we speculate that 1 in high-purity and low-concentration solutions is nonspecifically adsorbed onto the surfaces of the experimental tubes in a manner similar to the adsorption of unstable peptides [49], further research is necessary in this regard. In the future, we may establish a validated method for the quantitative analysis of ELE. 


\section{Materials and Methods}

\subsection{Materials}

The leaves of E. globulus, used as the test material, were obtained from K. Kobayashi \& Co. (Kobe, Japan). The extract of $100 \mathrm{~g}$ of dried leaves was obtained using $1 \mathrm{~kg}$ of ethanolwater $(1: 2, v / v)$ under reflux for $2 \mathrm{~h}$. The obtained extract was filtered, evaporated to dryness in vacuo, and used as ELE throughout the experiments. The yield was approximately $20 \%$ of the leaves. HPLC- and LC/MS-grade solvents were purchased from Nacalai Tesque, Inc. (Kyoto, Japan). Compounds (Figure 2; oenothein B (1), quercetin 3-O- $\beta$-D-glucuronide (4), and kaempferol 3-O- $\beta$-D-glucuronide (5)) used as test samples in the sugar absorption assays were isolated from ELE [23]; cytochalasin B and gallic acid (2) were purchased from Fujifilm Wako Pure Chemical Co. (Osaka, Japan) and ellagic acid (3) from SigmaAldrich Japan (Tokyo, Japan). Other reagents mentioned elsewhere in the text with the manufacturer's name not specified were purchased from Nacalai Tesque, Inc. (Kyoto, Japan) or Fujifilm Wako Pure Chemical Co. (Osaka, Japan).

\subsection{Cells}

The human intestinal epithelial cell line Caco-2 was obtained from Dainippon Sumitomo Pharma (Osaka, Japan). The cells were cultured according to a previous method (described in Section 27.5.4 of that report [50]). BD Falcon cell culture inserts and 6-well cluster plates (BD Biosciences, Franklin Lakes, NJ, USA; Catalogue No. 353090) were used for cultivation of Caco-2 cells and the fructose absorption assay. In brief, subcultured cells were allowed to reach confluence in Dulbecco's modified Eagle's medium (DMEM; Sigma-Aldrich Japan, Tokyo, Japan; Catalogue No. D5796) containing 10\% fetal calf serum (Biowest, Nuaillé, France) and 1\% nonessential amino acids (Sigma-Aldrich, Tokyo, Japan; Catalogue No. M7145), and seeded on the inside of the insert at a density of $2 \times 10^{5}$ cells/insert. The DMEM was changed both apically (inside the insert) and basolaterally (the plate) every 3-4 days. Cells were allowed to differentiate for 3 weeks.

\subsection{Measurement of Fructose and Glucose Absorption Inhibitory Activity}

After confirming the purity to be $>95 \%$ by reversed-phase HPLC, the isolated compounds 1, 4, and 5 were used for subsequent experiments. Each sample solution was prepared by dissolution of test sample in $10 \%$ dimethyl sulfoxide.

The fructose absorption assay was conducted according to a previous method (described in Section 27.5.4 [50]). Briefly, both the inside and outside of the inserts were washed with $1 \mathrm{~mL}$ of phosphate-buffered saline without magnesium and calcium ( $\mathrm{pH}$ 7.4). Dulbecco's phosphate-buffered saline (1 mL; pH 7.4; Gibco, Langley, OK, USA; catalog no. 21300-025), which is glucose-free, was used as a medium for the absorption experiment, and was added to the plate and the inside of the insert. The cells were incubated for $30 \mathrm{~min}$ at $37{ }^{\circ} \mathrm{C}$ in a humidified incubator containing $5 \% \mathrm{CO}_{2}$. Monolayer formation by Caco-2 cells was confirmed by measuring TEER of the medium between the plate and in the inside of the insert using the Millicell-ERS Voltohmmeter (Millipore, Bedford, MA, USA). Next, $10 \mu \mathrm{L}$ of sample solution was added to the medium on the inside of the insert, followed by incubation for $5 \mathrm{~min}$ at $37^{\circ} \mathrm{C}$ in a humidified incubator containing $5 \% \mathrm{CO}_{2}$. Subsequently, $10 \mu \mathrm{L}$ of $100 \mathrm{mM}$ fructose solution (final concentration, $1 \mathrm{mM}$ ) was added to the medium on the inside of the insert, and the cells were incubated for an additional $3 \mathrm{~h}$ at $37^{\circ} \mathrm{C}$ at the same conditions. The TEER was measured again, and the medium in the plate was collected and stored at $-20^{\circ} \mathrm{C}$ in a sterile tube. The fructose concentration in the medium was analyzed using a previously described fructose-dehydrogenase-based method [28,50]. To examine the inhibitory effect of the sample on glucose absorption, we added $100 \mathrm{mM}$ glucose, instead of fructose, solution to the medium in the inside of the insert, after $10 \mu \mathrm{L}$ of the sample solution was added and preincubated for $5 \mathrm{~min}$ at $37{ }^{\circ} \mathrm{C}$ in a humidified incubator containing $5 \% \mathrm{CO}_{2}$. The plates were incubated for $3 \mathrm{~h}$ under the same conditions as those of the fructose absorption assay. The glucose concentration (final concentration, 
$1 \mathrm{mM}$ ) in the medium was analyzed using the Glucose CII Test Wako kit (Fujifilm Wako Pure Chemical Co., Osaka, Japan).

\subsection{Treatment of ELE with PVPP}

An ELE (1 g) aliquot was mixed with $10 \mathrm{~g}$ PVPP (Polyclar VT; ISP Japan, Tokyo, Japan) in $30 \%$ ethanol $(v / v)$. This mixture was stirred at room temperature $\left(25^{\circ} \mathrm{C}\right)$ for $1 \mathrm{~h}$. Subsequently, the mixture was centrifuged at $1000 \times g$ for $15 \mathrm{~min}$ at $25^{\circ} \mathrm{C}$ and filtered. A PVPP-treated ELE was obtained by concentration in vacuo and lyophilization of the filtrate (yield, 26\%).

\subsection{Measurement of Total Polyphenol Content}

The total polyphenol content of ELE and PVPP-treated ELE was measured in terms of gallic acid equivalents according to a previously described method [51] with modifications. Test samples and gallic acid were dissolved in purified water and sonicated for $5 \mathrm{~min}$. Anhydrous sodium carbonate was used for preparing $20 \% \mathrm{Na}_{2} \mathrm{CO}_{3}$ solution $(w / v)$. Sample solution $(500 \mu \mathrm{L})$ was mixed with $500 \mu \mathrm{L}$ of Phenol Reagent Solution (acid degree, $1.8 \mathrm{~N}$; Nacalai Tesque, Inc., Kyoto, Japan), and $1.5 \mathrm{~mL}$ of $20 \% \mathrm{Na}_{2} \mathrm{CO}_{3}$ solution was added immediately. After vortexing, each solution was allowed to stand at room temperature $\left(25^{\circ} \mathrm{C}\right)$ for $20 \mathrm{~min}$, after which the absorbance was respectively measured at $720 \mathrm{~nm}$.

\subsection{HPLC-DAD-ESI-MS Analysis of ELE}

The samples were dissolved in a water/methanol $(50: 50 ; v / v)$ solution and filtered through a TORAST Disc GLCTD-HPTFE1322 hydrophilic PTFE membrane filter (pore size, $0.22 \mu \mathrm{m}$; Shimadzu GLC Ltd., Kyoto, Japan). The filtrate was added to a glass vial (TORASTH Glass Vial; Shimadzu GLC Ltd., Kyoto, Japan) and set on a vial tray in the autosampler at $4{ }^{\circ} \mathrm{C}$. ELE analysis was conducted using Shimadzu Nexera X2 (Shimadzu Co., Kyoto, Japan) equipped with SPD-M30A (Shimadzu Co., Kyoto, Japan) as DAD according to previously reported methods $[23,52]$ with slight modifications. The conditions of LC using a Cosmosil 5C18-PAQ packed column (Nacalai Tesque, Inc., Kyoto, Japan; $5 \mu \mathrm{m}, 150 \mathrm{~mm} \times 2.0 \mathrm{~mm}$ i.d.) were as follows: column temperature, $40^{\circ} \mathrm{C}$; flow rate, $0.7 \mathrm{~mL} / \mathrm{min}$; and injection volume, $3 \mu \mathrm{L}$. UV spectra were recorded over a range of $220-350 \mathrm{~nm}$ and chromatograms were acquired at $270 \mathrm{~nm}$. The time programs of the mobile phase were conducted with a linear gradient in reversed-phase mode using a water/formic acid $(1000: 1 ; v / v)$ solution as solvent $A$ and acetonitrile as solvent $B$. The gradient program was $0-16 \% \mathrm{~B}$ in $\mathrm{A}$ in $9 \mathrm{~min}$, $16-45 \%$ B in A in $11 \mathrm{~min}, 45-95 \%$ B in A in $1 \mathrm{~min}, 95 \%$ B in A for $2 \mathrm{~min}$, and $95-100 \%$ B in A in $1 \mathrm{~min}$.

The identification of compound $\mathbf{1}$ was conducted according to previously reported methods $[47,48]$. The mass spectroscopy equipment LCMS-8050 (Shimadzu Co., Kyoto, Japan) was connected to Shimadzu Nexera X2 following DAD in series. The LC eluate was introduced directly into the ESI interface without splitting. ESI-MS was operated in the negative ion mode using $\mathrm{Ar}$ as the collision gas at $350 \mathrm{kPa}$ with the following settings: probe voltage, $-2.5 \mathrm{kV}$; nebulizing gas $\left(\mathrm{N}_{2}\right)$ flow, $3.00 \mathrm{~L} / \mathrm{min}$; drying gas $\left(\mathrm{N}_{2}\right)$ flow rate, $10 \mu \mathrm{L} / \mathrm{min}$; curved desolvation line voltage, default values; curved desolvation line temperature, $200{ }^{\circ} \mathrm{C}$; heating gas $\left(\mathrm{N}_{2}\right)$ flow rate, $10 \mathrm{~L} / \mathrm{min}$; block heater temperature, $450{ }^{\circ} \mathrm{C}$; interface temperature, $400{ }^{\circ} \mathrm{C}$; and analysis mode, multiple reaction monitoring. The identification of $\mathbf{1}(m / z 783.00)$ representing $[\mathrm{M}-2 \mathrm{H}]^{2-}$ was confirmed by comparing the observed molecular ions and their retention times. The product ions $m / z 765.00$ (collision energy, $23 \mathrm{~V}$ ), 300.85 (collision energy, $43 \mathrm{~V}$ ), and 275.00 (collision energy, $39 \mathrm{~V}$ ) obtained from $m / z 783.00$ as a precursor ion were also analyzed for the identification.

\section{Conclusions}

Taken together, the findings of this study showed that oenothein B (1), a major constituent and a significant marker characteristic to E. globulus leaves, is an active constituent of the ELE and inhibits fructose absorption in intestinal cells, as observed during an in vitro 
intestinal permeability model assay. To the best of our knowledge, this is the first study to report that oenothein B in ELE strongly inhibits intestinal fructose absorption. ELE can be manufactured stably and inexpensively, owing to the ease of availability of the E. globulus leaves as the ELE source since this species is distributed worldwide. ELE containing oenothein B is expected to prevent and ameliorate obesity and diseases such as NAFLD, diabetes mellitus, and hypertension that are caused by the dietary consumption of fructose. However, the amount of oenothein B in ELE could not be assessed. In the future, we wish to validate a method for the quantitative analysis of ELE.

Author Contributions: Conceptualization, K.S., K.N. and H.I.; data curation, K.S., H.T. and H.I.; funding acquisition, K.N.; investigation, K.S., M.A. and H.T.; methodology, K.S., M.A., H.T., Y.A., T.F., S.T. and H.I.; project administration, K.N. and H.I.; resources; M.Y. and Y.A.; writing-original draft preparation, K.S.; writing-review and editing, M.Y., Y.A., T.F., S.T. and H.I. All authors have read and agreed to the published version of the manuscript.

Funding: This research was funded in part by the research and development support program for regional revitalization in the food industry sector of the Ministry of Agriculture, Forestry and Fisheries, and a grant-in-aid to promote basic research by research personnel in private-sector business from the Japan Science and Technology Agency.

Institutional Review Board Statement: Not applicable.

Informed Consent Statement: Not applicable.

Acknowledgments: The authors are grateful to Yoshimasa Nakamura, Okayama University, for their extensive discussions. The authors also thank Hajime Ohigashi, Kyoto University, and Akira Murakami, Hyogo Prefecture University, for their help in developing the fructose absorption assay involving Caco-2 cells.

Conflicts of Interest: K.S. and K.N. are employees of Nagaoka Co., Ltd. H.I. received funding from Nagaoka Co., Ltd. The other authors do not have any conflicts of interest. The funders had no role in the design of the study; in the collection, analyses, or interpretation of data; in the writing of the manuscript, or in the decision to publish the results.

Sample Availability: Samples of the compounds are not available from the authors.

\section{References}

1. Johnson, R.J.; Segal, M.S.; Sautin, Y.; Nakagawa, T.; Feig, D.I.; Kang, D.H.; Gersch, M.S.; Benner, S.; Sánchez-Lozada, L.G. Potential role of sugar (fructose) in the epidemic of hypertension, obesity and the metabolic syndrome, diabetes, kidney disease, and cardiovascular disease. Am. J. Clin. Nutr. 2007, 86, 899-906. [CrossRef] [PubMed]

2. Jensen, T.; Abdelmalek, M.F.; Sullivan, S.; Nadeau, K.J.; Green, M.; Roncal, C.; Nakagawa, T.; Kuwabara, M.; Sato, Y.; Kang, D.H.; et al. Fructose and sugar: A major mediator of non-alcoholic fatty liver disease. J. Hepatol. 2018, 68, 1063-1075. [CrossRef] [PubMed]

3. United States Department of Agriculture. Sugar: World Markets and Trade. Available online: https://www.fas.usda.gov/data/ sugar-world-markets-and-trade (accessed on 15 November 2021).

4. Stanhope, K.L.; Schwarz, J.M.; Keim, N.L.; Griffen, S.C.; Bremer, A.A.; Graham, J.L.; Hatcher, B.; Cox, C.L.; Dyachenko, A.; Zhang, W.; et al. Consuming fructose-sweetened, not glucose-sweetened, beverages increases visceral adiposity and lipids and decreases insulin sensitivity in overweight/obese humans. J. Clin. Investig. 2009, 119, 1322-1334. [CrossRef] [PubMed]

5. Softic, S.; Cohen, D.E.; Kahn, C.R. Role of dietary fructose and hepatic de novo lipogenesis in fatty liver disease. Dig. Dis. Sci. 2016, 61, 1282-1293. [CrossRef] [PubMed]

6. Takeuchi, M. Toxic AGEs (TAGE) theory: A new concept for preventing the development of diseases related to lifestyle. Diabetol. Metab. Syndr. 2020, 12, 105. [CrossRef] [PubMed]

7. Amani, S.; Fatima, S. Glycation with fructose: The bitter side of nature's own sweetener. Curr. Diabetes Rev. 2020, 16, 962-970. [CrossRef] [PubMed]

8. Elliott, S.S.; Keim, N.L.; Stern, J.S.; Teff, K.; Havel, P.J. Fructose, weight gain, and the insulin resistance syndrome. Am. J. Clin. Nutr. 2002, 76, 911-922. [CrossRef] [PubMed]

9. ter Horst, K.W.; Schene, M.R.; Holman, R.; Romijn, J.A.; Serlie, M.J. Effect of fructose consumption on insulin sensitivity in nondiabetic subjects: A systematic review and meta-analysis of diet-intervention trials. Am. J. Clin. Nutr. 2016, 104, 1562-1576. [CrossRef] [PubMed]

10. Federico, A.; Rosato, V.; Masarone, M.; Torre, P.; Dallio, M.; Romeo, M.; Persico, M. The role of fructose in non-alcoholic steatohepatitis: Old relationship and new insights. Nutrients 2021, 13, 1314. [CrossRef] [PubMed] 
11. Barone, S.; Fussell, S.L.; Singh, A.K.; Lucas, F.; Xu, J.; Kim, C.; Wu, X.; Yu, Y.; Amla, H.; Seidler, U.; et al. Slc2a5 (Glut5) is essential for the absorption of fructose in the intestine and generation of fructose-induced hypertension. J. Biol. Chem. 2009, 284, 5056-5066. [CrossRef] [PubMed]

12. Malik, V.S.; Li, Y.; Pan, A.; De Koning, L.; Schernhammer, E.; Willett, W.C.; Hu, F.B. Long-term consumption of sugar-sweetened and artificially sweetened beverages and risk of mortality in US adults. Circulation 2019, 139, 2113-2125. [CrossRef] [PubMed]

13. World Health Organization. WHO Calls on Countries to Reduce Sugars Intake Among Adults and Children. Available online: https://www.who.int/mediacentre/news/releases/2015/sugar-guideline/en/ (accessed on 15 November 2021).

14. Ishimoto, T.; Lanaspa, M.A.; Le, M.T.; Garcia, G.E.; Diggle, C.P.; Maclean, P.S.; Jackman, M.R.; Asipu, A.; Roncal-Jimenez, C.A.; Kosugi, T; et al. Opposing effects of fructokinase $\mathrm{C}$ and A isoforms on fructose-induced metabolic syndrome in mice. Proc. Natl. Acad. Sci. USA 2012, 109, 4320-4325. [CrossRef] [PubMed]

15. Ferraris, R.P.; Choe, J.Y.; Patel, C.R. Intestinal absorption of fructose. Annu. Rev. Nutr. 2018, 38, 41-67. [CrossRef] [PubMed]

16. Schwarz, J.M.; Noworolski, S.M.; Erkin-Cakmak, A.; Korn, N.J.; Wen, M.J.; Tai, V.W.; Jones, G.M.; Palii, S.P.; Velasco-Alin, M.; Pan, K.; et al. Effects of dietary fructose restriction on liver fat, de novo lipogenesis, and insulin kinetics in children with obesity. Gastroenterology 2017, 153, 743-752. [CrossRef] [PubMed]

17. Lustig, R.H.; Mulligan, K.; Noworolski, S.M.; Tai, V.W.; Wen, M.J.; Erkin-Cakmak, A.; Gugliucci, A.; Schwarz, J.M. Isocaloric fructose restriction and metabolic improvement in children with obesity and metabolic syndrome. Obesity 2016, 24, 453-460. [CrossRef] [PubMed]

18. Simons, N.; Veeraiah, P.; Simons, P.I.H.G.; Schaper, N.C.; Kooi, M.E.; Schrauwen-Hinderling, V.B.; Feskens, E.J.M.; van der Ploeg, E.M.C.L.; Van den Eynde, M.D.G.; Schalkwijk, C.G.; et al. Effects of fructose restriction on liver steatosis (FRUITLESS); a double-blind randomized controlled trial. Am. J. Clin. Nutr. 2021, 113, 391-400. [CrossRef] [PubMed]

19. Domínguez-Coello, S.; Carrillo-Fernández, L.; Gobierno-Hernández, J.; Méndez-Abad, M.; Borges-Álamo, C.; García-Dopico, J.A.; Aguirre-Jaime, A.; León, A.C. Decreased consumption of added fructose reduces waist circumference and blood glucose concentration in patients with overweight and obesity. The DISFRUTE Study: A randomised trial in primary care. Nutrients 2020, 12, 1149. [CrossRef] [PubMed]

20. Hajeski, N.J. National Geographic Complete Guide to Herbs and Spices: Remedies, Seasonings, and Ingredients to Improve Your Health and Enhance Your Life; National Geographic Society: Washington, DC, USA, 2016.

21. Gray, A.M.; Flatt, P.R. Antihyperglycemic actions of Eucalyptus globulus (Eucalyptus) are associated with pancreatic and extrapancreatic effects in mice. J. Nutr. 1998, 128, 2319-2323. [CrossRef] [PubMed]

22. Amakura, Y.; Umino, Y.; Tsuji, S.; Ito, H.; Hatano, T.; Yoshida, T.; Tonogai, Y. Constituents and their antioxidative effects in eucalyptus leaf extract used as a natural food additive. Food Chem. 2002, 77, 47-56. [CrossRef]

23. Amakura, Y.; Yoshimura, M.; Sugimoto, N.; Yamazaki, T.; Yoshida, T. Marker constituents of the natural antioxidant Eucalyptus leaf extract for the evaluation of food additives. Biosci. Biotechnol. Biochem. 2009, 73, 1060-1065. [CrossRef] [PubMed]

24. Nagata, H.; Inagaki, Y.; Tanaka, M.; Ojima, M.; Kataoka, K.; Kuboniwa, M.; Nishida, N.; Shimizu, K.; Osawa, K.; Shizukuishi, S. Effect of eucalyptus extract chewing gum on periodontal health: A double-masked, randomized trial. J. Periodontol. 2008, 79, 1378-1385. [CrossRef] [PubMed]

25. Shiraishi, T.; Nakagawa, Y.; Nakagawa, M.; Kawai, Y.; Nagaoka, E.; Konno, T.; Ishikawa, S.; Inoue, M.; Hasebe, K.; Tamura, S Efficacy of new skin care hand cream when used by nurses. Jpn. J. Pharm. Health Care Sci. 2006, 32, 1275-1279. [CrossRef]

26. Inoue, S. Report of the MHLW-Grant-in-Aid Research Project: Hazard-Based Peer-Review Studies on the Safety Surveillance of Existing Food Additives; Ministry of Health, Labor and Welfare of Japan: Tokyo, Japan, 2007; pp. 14-15. Available online: http://www. mhlw.go.jp/shingi/2007/07/dl/s0704-7k.pdf (accessed on 15 November 2021).

27. Sugimoto, K.; Nakagawa, K.; Fujiwara, S.; Sakano, K.; Ebihara, S. Safety assessment of eucalyptus leaf extract oral consumption for 4 weeks in human subjects: A pilot study. Jpn. J. Complement. Alternat. Med. 2020, 17, 23-31. [CrossRef]

28. Sugimoto, K.; Suzuki, J.; Nakagawa, K.; Hayashi, S.; Fujita, T.; Yamaji, R.; Inui, H.; Nakano, Y. Eucalyptus leaf extract inhibits intestinal fructose absorption, and suppresses adiposity due to dietary sucrose in rats. Br. J. Nutr. 2005, 93, 957-963. [CrossRef] [PubMed]

29. Sugimoto, K.; Kawasaki, T.; Tomoda, M.; Nakagawa, K.; Hayashi, S.; Inui, H.; Kajimoto, T.; Yamanouchi, T. Lowering of postprandial hyperfructosemia in humans by eucalyptus leaf extract: A randomized, double-blind, placebo-controlled crossover study. Food Sci. Technol. Res. 2010, 16, 509-512. [CrossRef]

30. Gonçalves, A.S.; Andrade, N.; Martel, F. Intestinal fructose absorption: Modulation and relation to human diseases. Pharma Nutr. 2020, 14, 100235. [CrossRef]

31. Hidalgo, I.J.; Raub, T.J.; Borchardt, R.T. Characterization of the human colon carcinoma cell line (Caco-2) as a model system for intestinal epithelial permeability. Gastroenterology 1989, 96, 736-749. [CrossRef] [PubMed]

32. Schreck, K.; Melzig, M.F. Intestinal saturated long-chain fatty acid, glucose and fructose transporters and their inhibition by natural plant extracts in Caco-2 cells. Molecules 2018, 23, 2544. [CrossRef] [PubMed]

33. Andrade, N.; Araújo, J.R.; Correia-Branco, A.; Carletti, J.V.; Martel, F. Effect of dietary polyphenols on fructose uptake by human intestinal epithelial (Caco-2) cells. J. Funct. Foods 2017, 36, 429-439. [CrossRef]

34. Concha, I.I.; Velásquez, F.V.; Martínez, J.M.; Angulo, C.; Droppelmann, A.; Reyes, A.M.; Slebe, J.C.; Vera, J.C.; Golde, D.W. Human erythrocytes express GLUT5 and transport fructose. Blood 1997, 89, 4190-4195. [CrossRef] [PubMed] 
35. Gao, S.; Satsu, H.; Makino, T. Inhibitory effect of bofutsushosan (fang feng tong sheng san) on glucose transporter 5 function in vitro. J. Nat. Med. 2018, 72, 530-536. [CrossRef] [PubMed]

36. Gauer, J.S.; Tumova, S.; Lippiat, J.D.; Kerimi, A.; Williamson, G. Differential patterns of inhibition of the sugar transporters GLUT2, GLUT5 and GLUT7 by flavonoids. Biochem. Pharmacol. 2018, 152, 11-20. [CrossRef] [PubMed]

37. George Thompson, A.M.; Iancu, C.V.; Nguyen, T.T.; Kim, D.; Choe, J.Y. Inhibition of human GLUT1 and GLUT5 by plant carbohydrate products; insights into transport specificity. Sci. Rep. 2015, 5, 12804. [CrossRef] [PubMed]

38. Kerimi, A.; Gauer, J.S.; Crabbe, S.; Cheah, J.W.; Lau, J.; Walsh, R.; Cancalon, P.F.; Williamson, G. Effect of the flavonoid hesperidin on glucose and fructose transport, sucrase activity and glycaemic response to orange juice in a crossover tri-al on healthy volunteers. Br. J. Nutr. 2019, 121, 782-792. [CrossRef] [PubMed]

39. Lee, Y.; Lim, Y.; Kwon, O. Selected phytochemicals and culinary plant extracts inhibit fructose uptake in Caco-2 cells. Molecules 2015, 20, 17393-17404. [CrossRef] [PubMed]

40. Loureiro, G.; Martel, F. The effect of dietary polyphenols on intestinal absorption of glucose and fructose: Relation with obesity and type 2 diabetes. Food Rev. Int. 2019, 35, 390-406. [CrossRef]

41. Satsu, H.; Awara, S.; Unno, T.; Shimizu, M. Suppressive effect of nobiletin and epicatechin gallate on fructose uptake in human intestinal epithelial Caco-2 cells. Biosci. Biotechnol. Biochem. 2018, 82, 636-646. [CrossRef] [PubMed]

42. Slavic, K.; Derbyshire, E.T.; Naftalin, R.J.; Krishna, S.; Staines, H.M. Comparison of effects of green tea catechins on apicomplexan hexose transporters and mammalian orthologues. Mol. Biochem. Parasitol. 2009, 168, 113-116. [CrossRef] [PubMed]

43. Zakłos-Szyda, M.; Pietrzyk, N.; Kowalska-Baron, A.; Nowak, A.; Chałaśkiewicz, K.; Ratajewski, M.; Budryn, G.; Koziołkiewicz, M. Phenolics-rich extracts of dietary plants as regulators of fructose uptake in Caco-2 cells via GLUT5 involvement. Molecules 2021, 26, 4745. [CrossRef] [PubMed]

44. Makkar, H.P.S. Quantification of Tannins in Tree and Shrub Foliage; Kluwer Academic Publishers: Dordrecht, The Netherlands, 2003; p. 5 .

45. Yoshida, T.; Yoshimura, M.; Amakura, Y. Chemical and biological significance of oenothein B and related ellagitannin oligomers with macrocyclic structure. Molecules 2018, 23, 552. [CrossRef] [PubMed]

46. Jang, C.; Wada, S.; Yang, S.; Gosis, B.; Zeng, X.; Zhang, Z.; Shen, Y.; Lee, G.; Arany, Z.; Rabinowitz, J.D. The small intestine shields the liver from fructose-induced steatosis. Nat. Metab. 2020, 2, 586-593. [CrossRef] [PubMed]

47. Baert, N.; Karonen, M.; Salminen, J.P. Isolation, characterisation and quantification of the main oligomeric macrocyclic ellagitannins in Epilobium angustifolium by ultra-high performance chromatography with diode array detection and electrospray tandem mass spectrometry. J. Chromatogr. A 2015, 1419, 26-36. [CrossRef] [PubMed]

48. Tóth, B.H.; Blazics, B.; Kéry, A. Polyphenol composition and antioxidant capacity of Epilobium species. J. Pharm. Biomed. Anal. 2009, 49, 26-31. [CrossRef] [PubMed]

49. John, H.; Walden, M.; Schäfer, S.; Genz, S.; Forssmann, W.G. Analytical procedures for quantification of peptides in pharmaceutical research by liquid chromatography-mass spectrometry. Anal. Bioanal. Chem. 2004, 378, 883-897. [CrossRef] [PubMed]

50. Sugimoto, K.; Inui, H.; Yamanouchi, T. Chapter 27 Assays of fructose in experimental nutrition. In Dietary Sugars: Chemistry, Analysis, Function and Effects; Preedy, V.R., Ed.; The Royal Society of Chemistry: Cambridge, UK, 2012; pp. 464-483. [CrossRef]

51. Julkunen-Tiitto, R. Phenolic constituents in the leaves of northern willows: Methods for the analysis of certain phenolics. J. Agric. Food Chem. 1985, 33, 213-217. [CrossRef]

52. Arapitsas, P. Hydrolyzable tannin analysis in food. Food Chem. 2012, 135, 1708-1717. [CrossRef] [PubMed] 